\title{
Genomic features separating ten strains of Neorhizobium galegae with different symbiotic phenotypes
}

Janina Österman ${ }^{1,2}$, Seyed Abdollah Mousavi ${ }^{1,2}$, Patrik Koskinen ${ }^{3}$, Lars Paulin ${ }^{3}$ and Kristina Lindström²*

\begin{abstract}
Background: The symbiotic phenotype of Neorhizobium galegae, with strains specifically fixing nitrogen with either Galega orientalis or G. officinalis, has made it a target in research on determinants of host specificity in nitrogen fixation. The genomic differences between representative strains of the two symbiovars are, however, relatively small. This introduced a need for a dataset representing a larger bacterial population in order to make better conclusions on characteristics typical for a subset of the species. In this study, we produced draft genomes of eight strains of $N$. galegae having different symbiotic phenotypes, both with regard to host specificity and nitrogen fixation efficiency. These genomes were analysed together with the previously published complete genomes of N. galegae strains HAMBI 540 and HAMBI 1141.

Results: The results showed that the presence of an additional rpoN sigma factor gene in the symbiosis gene region is a characteristic specific to symbiovar orientalis, required for nitrogen fixation. Also the nifQ gene was shown to be crucial for functional symbiosis in both symbiovars. Genome-wide analyses identified additional genes characteristic of strains of the same symbiovar and of strains having similar plant growth promoting properties on Galega orientalis. Many of these genes are involved in transcriptional regulation or in metabolic functions.

Conclusions: The results of this study confirm that the only symbiosis-related gene that is present in one symbiovar of $N$. galegae but not in the other is an rpoN gene. The specific function of this gene remains to be determined, however. New genes that were identified as specific for strains of one symbiovar may be involved in determining host specificity, while others are defined as potential determinant genes for differences in efficiency of nitrogen fixation.
\end{abstract}

Keywords: Neorhizobium galegae, Symbiosis, Genome, rpoN, nifQ, Nitrogen fixation

\section{Background}

The nitrogen-fixing soil bacterium Neorhizobium galegae has an easily distinguishable phenotype on the host plant species Galega orientalis Lam. and G. officinalis L. It is the only rhizobial species known to induce root nodules on Galega plants so far, making studies of its genomics an attractive area in the field of research on determinants of host specificity and nitrogen fixation efficiency. Although research on nitrogen fixation with $N$. galegae has been conducted since the description of the new species in 1989 [1], the mechanism(s) behind the specific interactions between Galega plants and their microsymbiont is still not

\footnotetext{
* Correspondence: kristina.lindstrom@helsinki.fi

${ }^{2}$ Department of Environmental Sciences, University of Helsinki, Viikinkaari 2a, 00790 Helsinki, Finland

Full list of author information is available at the end of the article
}

well understood. The division of $N$. galegae strains into two symbiovars [2] with different phenotypes on the two host plant species brings further challenge into the study of this bacterium. Work has been done on the rhizobial signalling molecules, the Nod factors, of N. galegae [3,4], and the function of the rare acetyl substitution has been investigated. However, a clear explanation for the host specificity observed on Galega has not been found within the Nod factors. It is obvious that more information is needed both on characteristics distinguishing $N$. galegae from other rhizobial species but also strains within the species having different symbiotic phenotypes, as well as on characteristics of the host plant that may act to discriminate between strains of the same bacterial species.

The complete genomes of two strains of $N$. galegae were recently sequenced to shed some light on the basic 
genomic features separating $N$. galegae from other rhizobia and its symbiovars from each other [4]. The complete genome sequences of these strains, the type strain HAMBI $540^{\mathrm{T}}$ representing symbiovar (sv.) orientalis and strain HAMBI 1141 representing sv. officinalis, are invaluable to this research but not enough to observe genomic patterns related to the bacterial species or its symbiovars. Therefore, we have produced draft genomes of eight additional strains of $N$. galegae, four strains each of the symbiovars orientalis and officinalis, which combined with the previously sequenced complete genomes make a good representation of the $N$. galegae population. These data also enable a deeper study of the genomic patterns separating the two symbiovars as well as strains showing different nitrogenfixing capacities, than was previously possible. In this study, data from the eight newly sequenced strains were combined with the whole-genome data of strains HAMBI $540^{\mathrm{T}}$ and HAMBI 1141, and analysed to produce information on genomic characteristics of the species $N$. galegae. Analysis of subgroups within the species, defined by the symbiotic phenotypes observed on Galega plants, together with experimental evidence revealed that the sv. orientalisspecific rpoN2 gene as well as the nifQ gene are necessary for nitrogen fixation. Genes possibly related to enhanced plant growth promoting capabilities are also discussed.

\section{Results}

Symbiosis gene regions are well conserved within the symbiovars

Draft genomes of eight strains of $N$. galegae were produced, generating genomes consisting of between 54 and 148 contigs. The total size of the sequenced genome is between 6 and $7 \mathrm{Mbp}$ for all strains (Table 1), comprising two to four replicons per strain, as predicted by the number of rep $A B C$ operons and preliminary assembly of contigs. The eight new genomes were analysed together with the previously sequenced strains HAMBI $540^{\mathrm{T}}$ and HAMBI 1141 [4], to produce new information on the genomic differences separating strains of the two symbiovars.
Upon analysis of the nod, noe, nif and fix genes found in the gene regions corresponding to the symbiosis gene regions of HAMBI $540^{\mathrm{T}}$ and HAMBI 1141 [4], the gene content was found consistent with regard to the symbiovar (Figure 1). The same nod, noe, nif and fix genes can be found in all strains. The four sv. orientalis strains all share the nod, nif and fix gene structure found in strain HAMBI $540^{\mathrm{T}}$, with one exception: a predicted transposase gene located between the gene for the T1SS HlyD family protein and $\operatorname{nodN}$ in strain HAMBI 2605. Beside this minor difference, the symbiosis gene region only differs between strains in the genes separating the nodE - nodJ cluster from the $f i x U-n i f H$ gene cluster, as well as the genes separating nifH from nodU and nodU from the nodD2 - noeT gene cluster.

The analysed sv. officinalis strains have two main symbiosis gene region structures. Based on preliminary assembly of the contigs included in this region, strains HAMBI 490 and HAMBI 1146 had an almost identical gene content and gene arrangement (although there is no information on the exact sequence between nodJ and nifH in HAMBI 490), the only difference between the two being a predicted hypothetical protein located in between $f d x B$ and $f i x A$ in HAMBI 490. The symbiosis gene region of these two strains is also very similar to that found in strain HAMBI 1141 (Figure 1). On the other hand, strains HAMBI 1145 and HAMBI 1189 seem to have identical symbiosis gene regions, while differing from strains HAMBI 490 and HAMBI 1146 to some extent. The structure of the main gene clusters is the same, but the genes separating these nod, nif and fix gene clusters differ from those in the latter two strains both in the number of genes present and the predicted function of the same.

\section{The rpoN2 gene is specific to sv. orientalis strains}

In addition to the nod, noe, nif and fix genes, all sv. orientalis strains have a hypothetical protein gene followed by an rpoN gene copy included in the symbiosis gene region, similar to the situation in strain HAMBI $540^{\mathrm{T}}$. None of the analysed sv. officinalis strains have these

Table 1 Genome features and sequence data for $N$. galegae strains sequenced in this study

\begin{tabular}{|c|c|c|c|c|c|c|c|c|}
\hline & \multicolumn{4}{|l|}{ sv. officinalis } & \multicolumn{4}{|l|}{ sv. orientalis } \\
\hline & HAMBI 490 & HAMBI 1145 & HAMBI 1146 & HAMBI 1189 & HAMBI 2427 & HAMBI 2566 & HAMBI 2605 & HAMBI 2610 \\
\hline No. of contigs & 130 & 66 & 54 & 60 & 65 & 99 & 148 & 59 \\
\hline Coverage & 36 & 60 & 47 & 40 & 81 & 53 & 61 & 165 \\
\hline Total size of contigs (bp) & 6315871 & 6280747 & 6409219 & 6000372 & 6550167 & 6546417 & 6858028 & 6073615 \\
\hline No. of predicted genes & 6071 & 6027 & 6101 & 5781 & 6318 & 6289 & 6654 & 5792 \\
\hline No. of tRNAs identified ${ }^{a}$ & 44 & 44 & 43 & 44 & 43 & 44 & 43 & 44 \\
\hline No. of rRNA operons & 3 & 3 & 3 & 3 & 3 & 3 & 3 & 3 \\
\hline Sample accession number & ERS526350 & ERS526351 & ERS526352 & ERS526353 & ERS526354 & ERS526355 & ERS526356 & ERS526357 \\
\hline
\end{tabular}

${ }^{a}$ The contig containing the rRNA operon always contains three tRNA genes. Since this contig is always present in three copies in each genome, so are the tRNAs contained within this contig, adding six tRNAs to the total number of tRNAs encountered in the genome, making a total of 49 to 50 tRNAs identified per genome. 


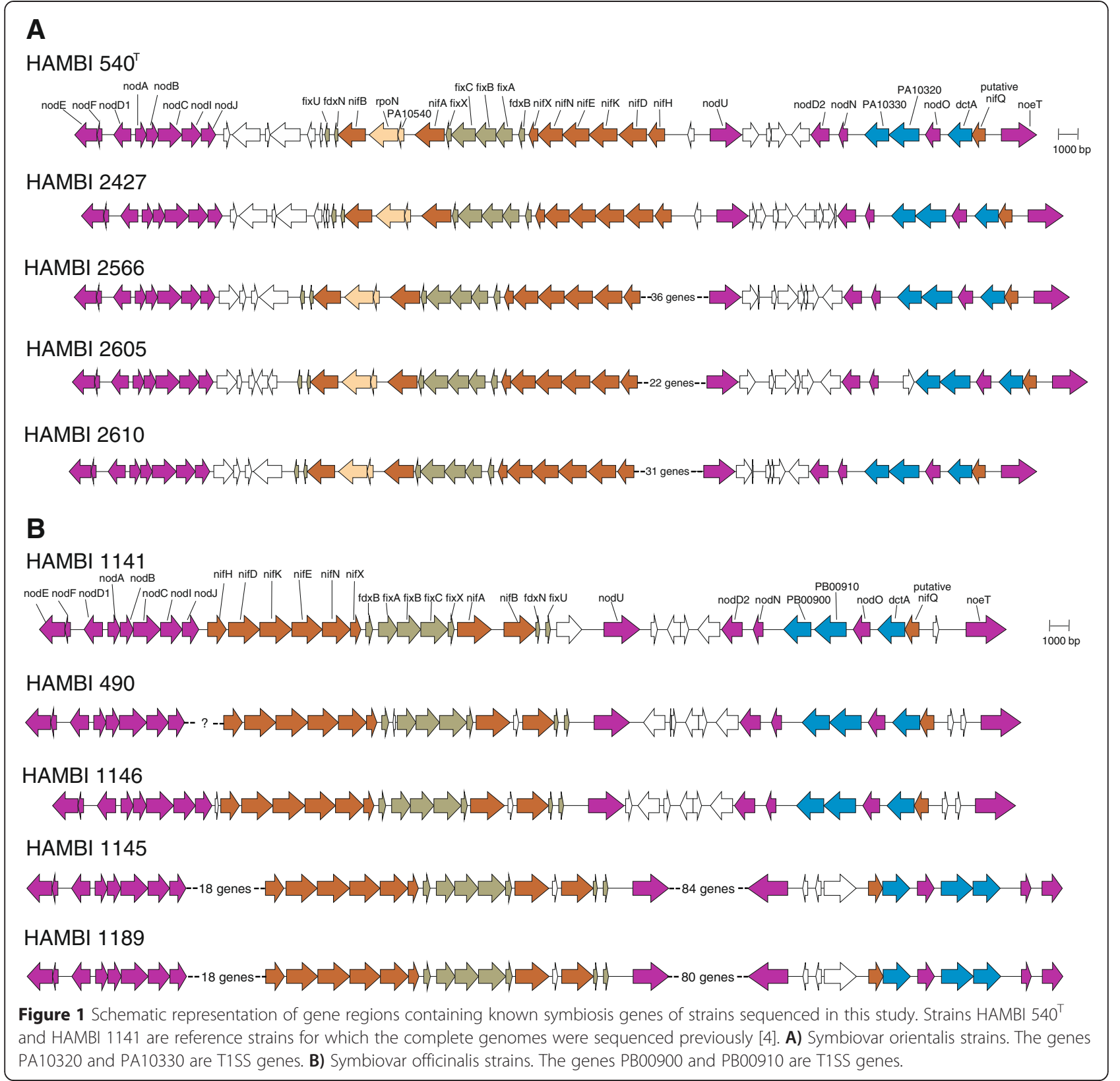

genes. The presence of a second rpoN gene in the symbiosis gene region was also confirmed a common characteristic of sv. orientalis strains when a set of nine $N$. galegae sv. orientalis strains (including HAMBI 540 , HAMBI 2605 and HAMBI 2610) were screened for this gene by PCR. The RpoN2 protein sequences of all five sequenced $N$. galegae sv. orientalis strains were $100 \%$ identical. On the other hand, there were some differences in the RpoN1 sequences of the eight strains where the complete rpoN1 sequence was available (i.e. all but strains HAMBI 2566 and HAMBI 2605). All eight RpoN1 sequences were between 91.5 and $99.6 \%$ identical, while the maximum sequence identity of RpoN2 to any of the RpoN1 sequences was $89.3 \%$.

A gene replacement deletion mutant of the rpoN2 gene was constructed in HAMBI $540^{\mathrm{T}}$ to test the impact on symbiosis. Location of the insert and intactness of other parts of the genome of the mutant was verified by genome sequencing and mapping to the reference genome of HAMBI $540^{\mathrm{T}}$. Upon inoculation of G. orientalis plants with the mutant strain (HAMBI 3480), nodules were formed but the inoculated plants showed growth comparable to that observed when inoculated with the ineffective sv. officinalis strain HAMBI 1141. Plants remained short and the leaves were very pale 
green, indicating that nitrogen fixation was impaired and that this copy of rpoN is required for functional symbiosis on G. orientalis.

\section{The nifQ gene is divergent but functional}

Another gene located in the symbiosis gene region that makes a clear distinction between strains of the two symbiovars is the nifQ gene. Alignment of the protein sequences deduced from this gene showed that the NifQ protein is well conserved within the symbiovars, while there was a remarkable amount of substitutions when sequences were compared between symbiovars (Figure 2). In addition, the NifQ sequences in N. galegae were highly divergent from those of the model species Azotobacter vinelandii and Klebsiella pneumoniae (Figure 2). The NifQ sequences of all five sv. orientalis strains were 100\% identical, while some minor differences in predicted start codon and location of the stop codon could be observed between strains of sv. officinalis.

Gene replacement deletion mutants were constructed also for nifQ in both HAMBI $540^{\mathrm{T}}$ and HAMBI 1141, and the mutant strains (HAMBI 3479 and HAMBI 3481 respectively) verified by genome sequencing and mapping to the respective reference strains. The mutant strains were tested on their respective host plants, generating results similar to those observed with the rpoN2 mutant.

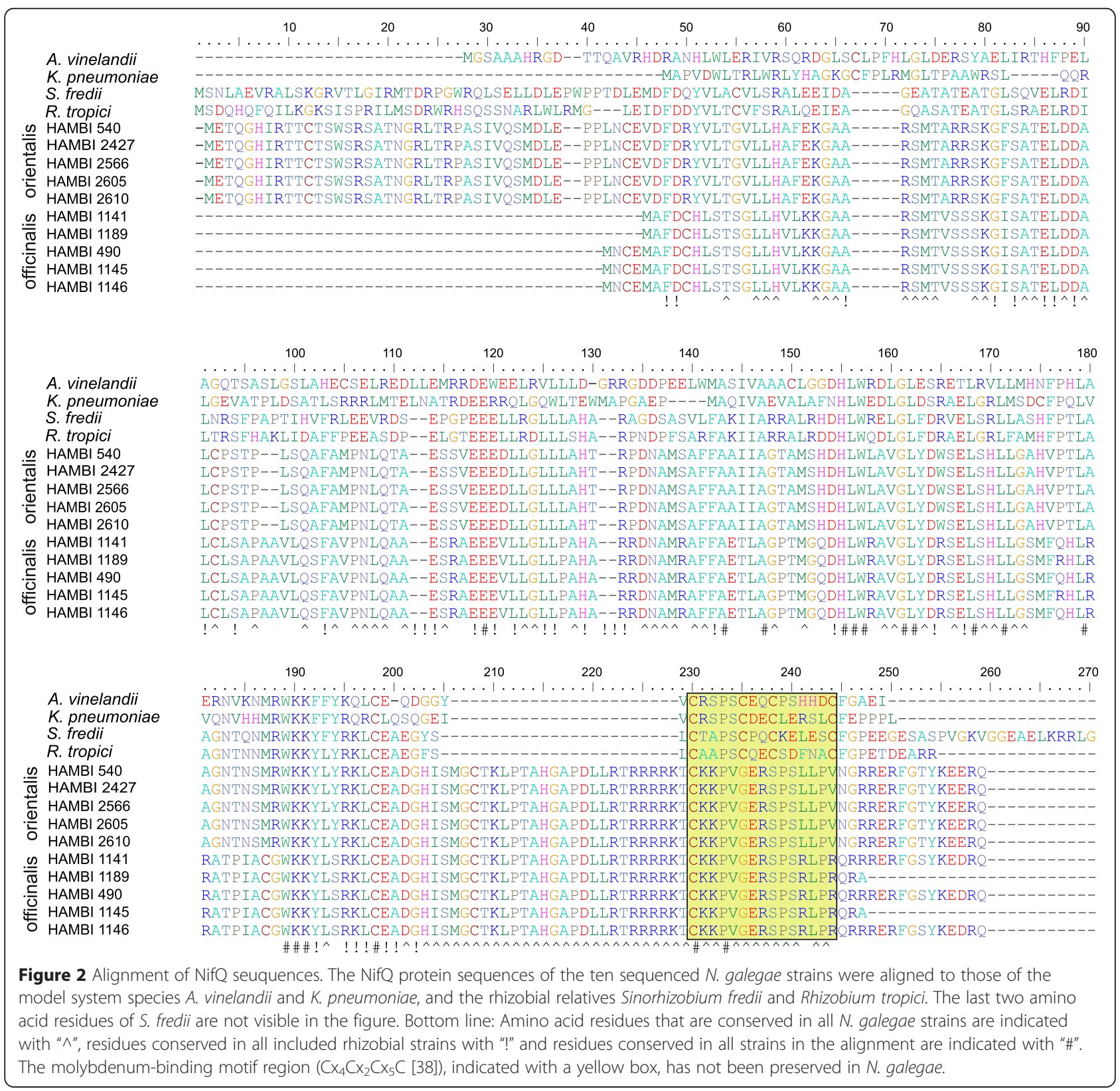


Plants were short and pale, clearly suffering from nitrogen deprivation, comparable to the outcome when G. orientalis is inoculated with sv. officinalis strain HAMBI 1141 and G. officinalis inoculated with sv. orientalis strain HAMBI $540^{\mathrm{T}}$. The nodules formed were small and white on G. officinalis, while nodules on G. orientalis were more pale pink or greenish, but still much more pale and smaller than effective nodules formed by wild-type HAMBI $540^{\mathrm{T}}$. Unfortunately, attempts to express the nifQ gene of HAMBI 1141 in HAMBI $540^{\mathrm{T}}$ and vice versa were not successful. However, these results indicate that even if the nifQ genes found in $N$. galegae have diverged from the corresponding genes in related rhizobial species, these are required for nitrogen fixation.

\section{Secretion systems of type IV and VI are common in N. galegae}

Because of their interesting ecological functions, the presence of type IV and type VI secretion systems (T4SSs and T6SSs) similar to those previously found in HAMBI $540^{\mathrm{T}}$ and HAMBI 1141 was investigated in the eight newly sequenced strains (Table 2). A T6SS was previously identified in HAMBI $540^{\mathrm{T}}$, while strain HAMBI 1141 has two different types of T4SSs [4]. The two T4SSs in HAMBI 1141 belong to the quorum sensing (QS)-regulated conjugation system (type I) and a type IV conjugation system, based on homology to systems assigned to these types defined by both structural and phylogenetic analyses by Ding and co-workers [5]. Among the three different kinds of secretion systems analysed in N. galegae, the T4SS of type I found on the symbiosis plasmid of HAMBI 1141 was the least well represented in the new strains. Although the T4SSs could be identified as being homologs of one of the two systems

Table 2 Type IV and type VI secretion systems in N. galegae genomes

\begin{tabular}{llll}
\hline & T4SS, type IV & T4SS, type I & T6SS $^{\text {a }}$ \\
\hline sv. officinalis strains & & & - \\
HAMBI $1141^{\text {b }}$ & + & + & - \\
HAMBI 490 & + & - & + \\
HAMBI 1145 & + & - & - \\
HAMBI 1146 & + & + & + \\
HAMBI 1189 & - & - & + \\
Sv. orientalis strains & & & + \\
HAMBI $540^{\text {b }}$ & - & - & + \\
HAMBI 2427 & + & - & + \\
HAMBI 2566 & - & - & - \\
HAMBI 2605 & + & + & + \\
HAMBI 2610 & - & - & + \\
\hline
\end{tabular}

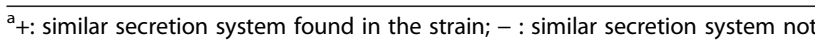
found in strain.

${ }^{\mathrm{b}}$ strain sequenced previously [4]. present in HAMBI 1141, the gene content was not always entirely the same as is found in HAMBI 1141. In HAMBI 1141 there is a tral/traR/traM QS regulation system present on the plasmid pHAMBI1141b together with the T4SS genes of type I. In HAMBI 490, there is what seems to be an incomplete set of QS-related genes located $16 \mathrm{~kb}$ from the T4SS of type IV, with two traR-like genes and one traI homolog but no traM gene. In HAMBI 2605, the traMR genes are present associated with the T4SS of type I, but no traI gene could be found. In addition, the traACDG genes are missing. However, the identified type I conjugation system genes in HAMBI 2605 are split onto two different contigs, and thus it is possible that the traIACDG genes could not be identified due to a gap in between these contigs. In the same strain there is also a T4SS of type IV with a virB8-like gene that is interrupted by a stop codon in the middle of the gene.

T6SS genes were found in strains HAMBI $540^{\mathrm{T}}$, HAMBI 2427, HAMBI 2566, HAMBI 2605, HAMBI 1145 and HAMBI 1189. These strains all have the same T6SS genes arranged in the same gene organisation, the whole gene region showing 83.1-85.0\% nucleotide identity compared to HAMBI $540^{\mathrm{T}}$, with the exception of strain HAMBI 2427 which has a nucleotide identity of $99.8 \%$. However, despite the relative abundance of these secretion systems observed in the sequenced $N$. galegae strains, the presence of a certain kind of secretion system could not be linked to strains of either symbiovar.

\section{Ortholog groups define genes common in specified subgroups}

Analysis of ortholog groups was performed on the proteomes of the ten sequenced $N$. galegae strains, to find genes typical for the species and those typical of subgroups of the species. Based on the 4255 ortholog groups shared by all ten strains, the core genome of $N$. galegae comprises between 4323 (HAMBI 1189) and $4346\left(\right.$ HAMBI $540^{\mathrm{T}}$ ) proteins per strain. The number of strain-specific genes (i.e. singletons in the OrthoMCL analysis) ranges from 111 in HAMBI 2610 to 456 in HAMBI 2605. To investigate whether there are symbiovarspecific genes that could be revealed through analysis of the CDSs of the ten sequenced strains, ortholog groups containing genes from all five strains of one symbiovar, but not a single gene of strains representing the other symbiovar, were targeted. This analysis revealed 40 orientalis-specific ortholog groups and 28 officinalis-specific ortholog groups (Table 3). The officinalis-specific genes are interesting in that all of the 23 genes which are not located on the chromosome of the reference genome, are located either within the symbiosis gene region defined by the nod, nif and fix genes, or within 38 genes downstream of nodE. Also among the orientalis-specific genes, $20 \%$ are located in the corresponding downstream region of $n o d E$ in HAMBI 
Table 3 Genes contained in the symbiovar-specific ortholog groups

\begin{tabular}{|c|c|c|c|}
\hline \multicolumn{2}{|c|}{ Orientalis-specific genes } & \multicolumn{2}{|c|}{ Officinalis-specific genes } \\
\hline $\begin{array}{l}\text { HAMBI } 540^{\top} \\
\text { locus tag }\end{array}$ & Gene function & $\begin{array}{l}\text { HAMBI } 1141 \\
\text { locus tag }\end{array}$ & Gene function \\
\hline PA12530 & Pimelyl-[acyl-carrier protein] methyl ester esterase & $\mathrm{CH} 10650$ & Mll9651 protein \\
\hline PA13300 & Drug resistance transporter, EmrB/QacA subfamily & $\mathrm{CH} 10640$ & RES domain protein \\
\hline PA12540 & Hypothetical protein & $\mathrm{CH} 06450$ & Hypothetical protein \\
\hline PA14750 & Helix-turn-helix protein, CopG & $\mathrm{CH} 06440$ & Hypothetical protein \\
\hline PA10390 & Transposase IS4 family protein & PB00510 & Hypothetical protein \\
\hline PA11760 & Putative dehydrogenase subunit & PB00490 ${ }^{d}$ & Hypothetical protein \\
\hline PA11750 & Gluconate 2-dehydrogenase (Acceptor) & PB00470 & Benzaldehyde dehydrogenase (NAD+) \\
\hline PA11740 & Transcriptional regulator, LysR family & PB00460 ${ }^{d}$ & $\begin{array}{l}\text { Sigma-54 interacting regulator, } \\
\text { V4R domain-containing protein }\end{array}$ \\
\hline PA11090 & Hypothetical protein & PB00420 & Transcriptional regulator \\
\hline PA11000 & Acyl-CoA synthetase & PB00410 & Fumarate hydratase \\
\hline PA10970 & Endoribonuclease L-PSP & PB00400 ${ }^{d}$ & Hypothetical protein \\
\hline PA10920 & Diaminopropionate ammonia-lyase & $\mathrm{PB} 00390^{\mathrm{d}}$ & $\begin{array}{l}\text { Putative 3-methylaspartate ammonia-lyase, } \\
\text { glutamate mutase }\end{array}$ \\
\hline PA10900 & Hippurate hydrolase & PB00380 ${ }^{d}$ & 3-alpha-hydroxysteroid dehydrogenase \\
\hline PA10890 & Hypothetical protein & PB00370 & Steroid C27-monooxygenase \\
\hline PA10880 & Hypothetical protein & PB00360 ${ }^{d}$ & Agmatinase \\
\hline PA10870 & Hypothetical protein & PB00350 ${ }^{d}$ & Hypothetical protein \\
\hline $\mathrm{CH} 26260$ & Cupin domain protein & PB00340 & 4-aminobutyrate transaminase \\
\hline $\mathrm{CH} 26240$ & Flavodoxin & PB00330 ${ }^{d}$ & Aldehyde dehydrogenase \\
\hline PA13080 & Transcriptional regulator SocA3 & PB00300 ${ }^{d}$ & Amino acid permease-associated region \\
\hline PA13090 & Glutathione S-transferase & PB00290 ${ }^{d}$ & Hypothetical protein \\
\hline $\mathrm{CH} 08120$ & Carboxymuconolactone decarboxylase & PB00280 & Cation/cationic drug transporter \\
\hline PA04570 & Hypothetical protein & PB00270 & NADH dehydrogenase \\
\hline PA10070 b & Hypothetical protein & PB00260 ${ }^{d}$ & Transcriptional regulator, TetR family \\
\hline PA10080 & Hypothetical protein & PB00230 & MFS transporter \\
\hline PA14930 & Transcriptional regulator, LysR family & PB00220 ${ }^{d}$ & L-lysine exporter \\
\hline PA14940 & Glyoxalase family protein & PB00210 & Transcriptional regulator, ArgP family \\
\hline PA15010 & Hypothetical protein & PB00950 & Hypothetical protein \\
\hline PA10270 & Hypothetical protein & $\mathrm{CH} 32360$ & Hypothetical protein \\
\hline PA07580 & Hypothetical protein & & \\
\hline PA09750 & Hypothetical protein & & \\
\hline PA10640 & Hypothetical protein & & \\
\hline $\mathrm{CH} 19720$ & Hypothetical protein & & \\
\hline PA10760 & Transposase IS116/IS110/IS902 family protein & & \\
\hline PA10540 & Hypothetical protein & & \\
\hline $\mathrm{CH} 11120$ & Antisigma-factor antagonist, STAS & & \\
\hline $\mathrm{CH} 43990$ & Hypothetical protein & & \\
\hline PA07480 & $\begin{array}{l}\text { Putative nitrilase/cyanide hydratase family protein } \\
\text { (Carbon-nitrogen hydrolase) }\end{array}$ & & \\
\hline
\end{tabular}


Table 3 Genes contained in the symbiovar-specific ortholog groups (Continued)

\begin{tabular}{|c|c|}
\hline $\mathrm{CH} 38090$ & Bacterial regulatory s, tetR family protein \\
\hline $\mathrm{CH} 38080$ & Hypothetical protein \\
\hline $\mathrm{CH} 38070$ & DoxX family protein \\
\hline
\end{tabular}

$540^{\mathrm{T}}$. In order to investigate a possible connection between the rpoN2 gene and orientalis-specific genes, the putative promoter regions of the orientalis-specific genes were scanned for possible RpoN binding sites in strain HAMBI $540^{\mathrm{T}}$. However, the only possible (although not perfect) motif found was located 238-223 bp upstream of the hypothetical protein gene PA10540.

Another OrthoMCL analysis was performed comparing the proteomes of HAMBI 540 ${ }^{\mathrm{T}}$, HAMBI 1141 and eight strains representing closely related rhizobial species (Rhizobium leguminosarum sv. viciae, R. leguminosarum sv. trifolii, R. etli, R. tropici, Sinorhizobium fredii, S. medicae, S. meliloti and Mesorhizobium ciceri). When the $N$. galegae-specific ortholog groups of this analysis were compared to the core genome of $N$. galegae revealed by the analysis of the ten $N$. galegae strains, finally 441 ortholog groups were found to be common to and specific for all N. galegae strains (Additional file 1). Among these, 139 groups consisted of hypothetical proteins, and based on current knowledge none of the remaining ones seem to be directly related to known symbiotic functions.

Based on results from a greenhouse experiment testing the plant growth promoting capacity of $N$. galegae strains, the Sv. orientalis strains HAMBI 540 ${ }^{\mathrm{T}}$, HAMBI 2427 and HAMBI 2566 are very good nitrogen fixers $\left(\right.$ fix $^{++}$), while strains HAMBI 2605 and HAMBI 2610 show a lower level of nitrogen fixation $\left(\mathrm{fix}^{+}\right.$) (Figure 3 ). To test whether there is a genomics-based pattern that could explain the differences in plant growth promoting efficiency, the OrthoMCL results were analysed from a point of view focusing on the nitrogen fixation properties of the strains. When ortholog groups containing genes shared by the fix ${ }^{++}$sv. orientalis strains but not present in the $\mathrm{fix}^{+}$strains were analysed, 54 such groups were found (Table 4). Among these groups, 11 were unique to the fix ${ }^{++}$sv. orientalis strains, i.e. genes not found in any other of the analysed strains but HAMBI 540 ${ }^{\mathrm{T}}$, HAMBI 2427 and HAMBI 2566.

\section{Discussion}

Eight draft genomes of $N$. galegae were produced to enable a more profound study of the bacterial genomics contributing to the host specificity observed in the nitrogen-fixing symbiosis between this bacterium and its host plants. Results of this study show that a major part of the genomes consist of genes common to all analysed $N$. galegae strains, while the two symbiovars can be separated based on a fairly limited set of genes only. The number of strain-specific genes varies a lot between strains, as does the number of replicons present, even if none of the sequenced strains has more than four replicons. Similar conclusions have been drawn for e.g. S. meliloti [6] and R. etli [7].

\section{T4SSs and T6SSs are probably not related to symbiosis in N. galegae}

Type IV and type VI secretion systems in bacteria are important machineries contributing to ecological functions. T4SSs contribute to horizontal gene transfer and might be responsible for transfer of symbiosis genes between strains. In Österman et al. 2014 [4] we speculated that the T6SS could play a role in the host specificity of $N$. galegae, being present in HAMBI $540^{\mathrm{T}}$ but not in HAMBI 1141. However, the present study shows that the presence of a certain secretion system can not be attributed to one symbiovar or the other, but these can be found in strains of both

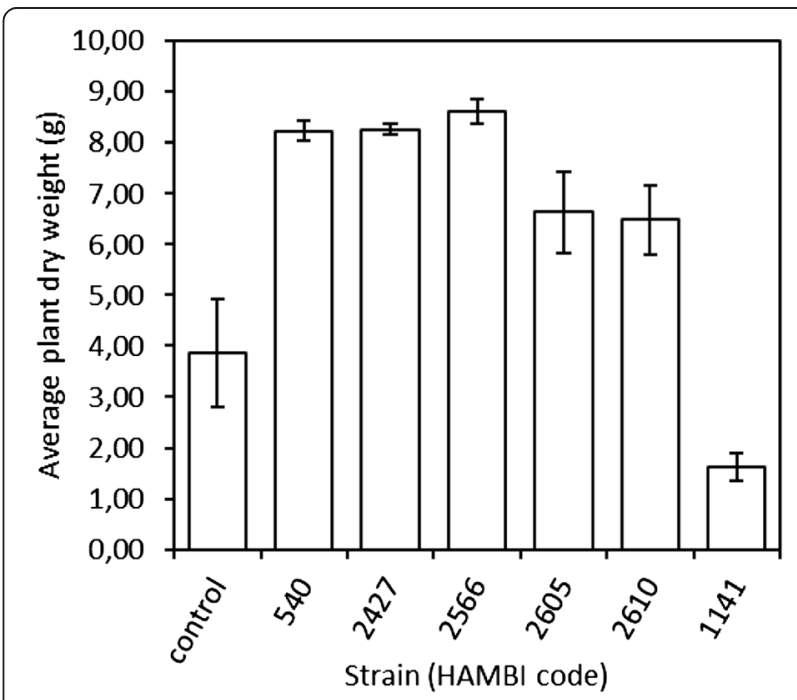

Figure 3 Average dry weight of G. orientalis plants inoculated with the genome-sequenced strains. "Control" is the uninoculated control, while HAMBI 1141 is included as a reference for ineffective strains. Dry weight values represent the sum of three plants grown in the same pot. Error bars represent standard error. $n=6$ for all strains except for HAMBI 2605 and HAMBI 2610 for which $n=5$. 
Table 4 Genes in sv. orientalis fix $^{++}$strains not present in fix ${ }^{+}$strains

\begin{tabular}{|c|c|c|c|}
\hline Gene annotation & $\begin{array}{l}\text { Locus tag in } \\
\text { HAMBI } 540^{\top}\end{array}$ & Gene annotation & $\begin{array}{l}\text { Locus tag in } \\
\text { HAMBI } 540^{\top}\end{array}$ \\
\hline Xaa-Pro dipeptidase & PA14880 & Nitric-oxide reductase subunit NorB & $\mathrm{CH} 35580$ \\
\hline Transposase IS116/IS110/IS902 family protein & PA10750 & Nitric-oxide reductase subunit NorC & $\mathrm{CH} 35570$ \\
\hline Topology modulation protein & $\mathrm{CH} 30350$ & Hypothetical protein & $\mathrm{CH} 35560$ \\
\hline Hypothetical protein & PA13020 & Nitric-oxide reductase NorE protein & $\mathrm{CH} 35550$ \\
\hline Hypothetical protein & PA13010 & Hypothetical protein & $\mathrm{CH} 35540$ \\
\hline PilT protein domain protein & $\mathrm{CH} 43490$ & NnrS family protein & $\mathrm{CH} 35670$ \\
\hline Hypothetical protein & $\mathrm{CH} 43480$ & Transcriptional regulator $\mathrm{NnrR}$ & $\mathrm{CH} 35660$ \\
\hline $\mathrm{N}$-methylhydantoinase B & PA14510 & Aromatic ring hydroxylating enzyme & $\mathrm{CH} 35650$ \\
\hline Hypothetical protein & $\mathrm{CH} 39310$ & Hypothetical protein & $\mathrm{CH} 35640$ \\
\hline Hypothetical protein & PA10050 & Transcriptional regulator & PA14580 \\
\hline Hypothetical protein & PA09720 & ABC transporter, substrate binding protein (Amino acid) & PA14530 \\
\hline RES domain protein & PA09710 & Amino acid $A B C$ transporter, permease protein & PA14540 \\
\hline SH3 type 3 domain-containing protein & PA09040 & Amino acid $A B C$ transporter, permease protein & PA14550 \\
\hline Cyanamide hydratase & PA08850 & General L-amino acid transport ATP-binding subunit & PA14560 \\
\hline Hypothetical protein & PA05600 & Endoribonuclease L-PSP & PA14570 \\
\hline Nitrogen regulatory protein NtrP & PA13210 & Phospholipase D/Transphosphatidylase & $\mathrm{CH} 44670$ \\
\hline Hypothetical protein & PA08870 & Chloride channel protein & PA04790 \\
\hline Hypothetical protein & $\mathrm{CH} 27770$ & Lactate dehydrogenase related enzyme & PA12720 \\
\hline Ribosomal protein P2 & $\mathrm{CH} 26410$ & Aliphatic sulfonates import ATP-binding protein SsuB & PA12620 \\
\hline Glutathionine S-transferase & $\mathrm{CH} 13510$ & Sulfonate/nitrate/taurine transport system permease & PA12610 \\
\hline GntR domain protein & PA14430 & $\begin{array}{l}\text { ABC transporter, substrate-binding protein, aliphatic } \\
\text { sulfonates family }\end{array}$ & PA12600 \\
\hline Zinc-binding oxidoreductase & PA01300 & $\begin{array}{l}\text { ABC-type nitrate/sulfonate/bicarbonate transport systems } \\
\text { periplasmic components-like protein }\end{array}$ & PA12590 \\
\hline Bacillibactin trilactone hydrolase & PA14790 & Transcriptional regulator GbdR & PA12410 \\
\hline Putative transmembrane protein & $\mathrm{CH} 35630$ & Gp49-like PF05973 family protein & PA13350 \\
\hline Amylo-alpha-1,6-glucosidase family protein & $\mathrm{CH} 35620$ & DNA-binding helix-turn-helix protein & PA13360 \\
\hline Protein NorD & $\mathrm{CH} 35600$ & Chromate transport protein & PA08760 \\
\hline Nitric oxide reductase protein NorQ & $\mathrm{CH} 35590$ & Hypothetical protein & $\mathrm{CH} 44690$ \\
\hline
\end{tabular}

Annotations according to function assigned to strain HAMBI 540 . Genes unique to symbiovar orientalis fix ${ }^{++}$strains (and thereby not present in any of the sv. officinalis strains) indicated in boldface.

symbiovars of N. galegae. There are some indications that the T4SSs found in N. galegae strains are undergoing changes. The atypical set of QS-related genes in strain HAMBI 490, which has a T4SS classified as type IV (which is not associated with QS regulation [5]), is not necessarily related to regulation of T4S. Moreover, it remains unknown whether the interrupted virB8-type gene in HAMBI 2605 renders this T4SS non-functional. The identified T6SS, on the other hand, seems well conserved in the strains of N. galegae where such a system is found.

The specific functions of rpoN2 and nifQ are important for nitrogen fixation

The presence of a gene coding for a hypothetical protein followed by a second $r p o N$ gene copy (i.e. another one in addition to the chromosomally located rpoN) in the symbiosis gene region appears to be a symbiovar orientalis-specific trait. The absence of amino acid substitutions in the RpoN2 proteins of the analysed strains indicates that the product of this second rpoN might perform a very specific function. When compared to the RpoN1 proteins, there is an accumulation of substitutions in the N-terminal region (region I). These differences might affect interactions with target DNA and activator proteins, resulting in transcription of different types of genes as observed in e.g. Rhodobacter sphaeroides [8] or transcription under different conditions. Two rpoN genes have been found also in other rhizobia, but the reported involvement in symbiosis differs. In Bradyrhizobium japonicum, both rpoN genes could replace each other functionally, although 
one of them was regulated in response to oxygen [9]. In $R$. etli, symbiotic nitrogen fixation was drastically reduced when the rpoN2 gene was mutated, while mutation of the rpoN1 gene did not affect nitrogen fixation levels [10]. The rpoN2 gene was not expressed aerobically, but was strongly induced in bacteroids. Also in Mesorhizobium loti, the rpoN2 gene located on the symbiosis island has been shown to be essential for nitrogen fixation, whereas the chromosomally located rpoN1 gene is dispensable for nitrogen fixation [11]. The results of this study clearly show that the rpoN2 gene of N. galegae is required for nitrogen fixation, but a possible function in determining host specificity should be further investigated. The hypothetical protein gene preceding the rpoN gene varies in size between strains, but is nonetheless always part of the same ortholog group. There are, however, no clues to the possible function of this gene.

The nifQ gene of $N$. galegae was previously the target of speculations that this gene is non-functional in this species, because of the apparent diversification of this gene from the corresponding gene in related species, as well as the lack of a molybdenum-binding motif [4]. However, this study showed that NifQ is in fact very well conserved within symbiovars, indicating that this could be an important protein after all. Gene replacement deletion studies performed in this work showed that the nifQ gene in both symbiovars is required for nitrogen fixation, although the importance of the observed differences in its protein sequence would deserve attention in future studies. Experiments with different levels of molybdenum could have been done to study the effect of the concentration of available molybdenum on the mutant phenotype. However, the results obtained with the conditions used provided enough evidence of the involvement of NifQ in symbiosis, leaving studies on the effect of the molybdenum level on functional symbiosis to the future.

\section{Analysis of ortholog groups revealed potential future target genes in research on the effectiveness of nitrogen fixation}

OrthoMCL analyses allowed the definition of the $N$. galegae core genome as well as a set of genes from the core genome that could not be found in related rhizobial species. Information about the core genome is useful when characteristics of all strains of $N$. galegae are studied, while information on the $N$. galegae-specific portion of the core genome might be useful when studying differences between $N$. galegae and other nitrogen fixers. More specifically, the OrthoMCL analysis of ten $N$. galegae strains revealed symbiovar-specific gene sets, as well as genes present in strains of sv. orientalis known to be good nitrogen fixers while missing in strains known to be less efficient plant growth promoters.
The genes found to be symbiovar-specific are mostly genes involved in transcriptional regulation and metabolic functions. These are not genes that have previously been directly associated with nitrogen fixation, but their possible involvement needs to be investigated in future experiments. In addition, as seen with the rpoN2 gene located in the symbiosis gene region of sv. orientalis strains, symbiovar-specific gene variants that have high sequence homology with other genes within the genome may not be detected as symbiovar-specific by the OrthoMCL analysis even if these are functionally different and obviously contribute to the pool of genes separating the two groups of strains. The possibility of the orientalis-specific genes being regulated by the orientalis-specific RpoN2 was investigated by searching for known RpoN binding motifs in upstream intergenic regions of these genes. The absence of probable RpoN binding motifs could mean that RpoN2 is either not connected to these genes or it is so specific that it recognises a modified RpoN binding motif compared to the known $-24 /-12$ promoter [12].

Among the genes typical for good N. galegae nitrogen fixers in sv. orientalis were the norEFCBQD genes, which are all part of the nitric oxide (NO) reductase [13], and the $n n r S R$ genes. The $n n r S$ gene codes for a haem- and copper-containing membrane protein that is regulated by the product of $n n r R$ [14]. These genes were also found as members of the accessory genome relevant for symbiotic interactions in S. meliloti [6]. NO production has been observed in functional nodules in bacteroidcontaining cells during Medicago truncatula - S. meliloti symbiosis [15] and has been found to have an important role in stress adaptation and the early stage of Lotus japonicus - M. loti symbiosis [16]. The fixLJ genes are positive regulators of symbiotic expression of nif and fix genes [17], but also expression of the nor genes is dependent on the FixLJ-FixK ${ }_{2}$ regulatory cascade in concert with NO-activated $n n r \mathrm{R}$ under microaerobic conditions $[18,19]$. In the light of this information, the presence of NO reduction genes in the efficient nitrogen fixers of $N$. galegae indicates that the possibility to reduce $\mathrm{NO}$ might be an advantage for nitrogen fixation.

B. japonicum USDA 110 has been found to express genes involved in organic sulphur utilisation in root nodules [20]. The transporter genes for aliphatic sulfonates also found in the sv. orientalis fix ${ }^{++}$-specific gene set are involved in transport of alternative sources of sulphur [21] that can be used for amino acid synthesis. This possibility might be an advantage for strains under stressful conditions.

Another gene found to be present in all superior sv. orientalis nitrogen fixers but none of the less efficient ones, was an $n t r P$ gene. The $n t r P$ gene is an antitoxin gene forming a toxin-antitoxin (TA) module with $n t r R$ in S. meliloti [22], found to regulate metabolic processes 
under stressful conditions such as those encountered when entering symbiosis. The presence of $n t r P$, binding to $n t r R$, lowers the negative effect of $n t r R$, thereby allowing a higher level of expression of genes favourable for nitrogen fixation [22].

\section{Conclusions}

Based on the genomic comparisons performed in this study, differences in genes known to be directly symbiosisrelated are small between strains of different symbiovars of $N$. galegae. Nevertheless, the observed symbiovar orientalisspecific rpoN2 gene as well as the nifQ gene, found in both symbiovars, were shown to be important for functional nitrogen fixation. The specific impact of these genes on host specificity should be further investigated. Secretion systems of type IV and type VI are common among strains of $N$. galegae, but do not seem to be involved in symbiotic functions. Based on the functional annotations of genes present in strains known to be good plant growth promoters but not in less efficient ones, an improved ability of nitrogen fixation seems to be correlated with an improved ability to use different metabolic substrates and an optimised regulation of metabolic functions under stressful conditions.

\section{Methods}

\section{Bacterial strains and growth conditions}

$N$. galegae strains used in this study are listed in Table 5 . All strains were obtained from the HAMBI culture collection (University of Helsinki, Department of Food and Environmental Sciences, Division of Microbiology and Biotechnology). Strains were grown on TY or YEM agar plates and in TY broth at $+28^{\circ} \mathrm{C}$.

\section{DNA isolation}

Total DNA of strains used for genome sequencing (Table 5) was isolated using a modified CTAB (hexadecyltrimethylammonium bromide) procedure as described in Österman et al. 2014 [4]. DNA for PCR screening was isolated from 6 additional strains of sv. orientalis (Table 5) using one of two different techniques. Most samples were prepared using an UltraClean Microbial DNA Isolation Kit (MO BIO Laboratories, Inc.), but DNA of strains HAMBI 2423 and HAMBI 2433 was prepared using the PrepMan Ultra Sample Preparation Reagent (Life Technologies), applying the protocol for preparation of samples for bacterial and fungal testing from culture broths.

\section{Screening for rpoN}

PCR screening for the second rpoN gene originally observed in the symbiosis gene region of HAMBI $540^{\mathrm{T}}$ [4] was performed using primers rpoN-25F (5'-CCGAGTCACACCCAATGTGC-3') and rpoN-1551R (5'-CGGACGGCCCGGCTATCC-3') internal to the HAMBI $540^{\mathrm{T}}$ gene. Amplification was done with Phusion High-Fidelity DNA Polymerase (Thermo Scientific) and the HF buffer, using a PCR cycle with initial denaturation at $98^{\circ} \mathrm{C} 30 \mathrm{~s}, 35$ cycles of denaturation $98^{\circ} \mathrm{C} 10 \mathrm{~s} \mathrm{-} \mathrm{anneal-}$ ing $69^{\circ} \mathrm{C} 30 \mathrm{~s}$ - elongation $72^{\circ} \mathrm{C} 50 \mathrm{~s}$, and final elongation at $72^{\circ} \mathrm{C}$ for $10 \mathrm{~min}$. PCR products were verified on a $1 \%$

Table 5 Strains used in this study and applications related to these

\begin{tabular}{|c|c|c|c|c|c|}
\hline Strain (HAMBI code) & Symbiovar & Application $^{a}$ & Geographical origin & Relevant alternative strain code & Reference(s) \\
\hline $540^{\top}$ & orientalis & Gen. seq., PCR & Finland & & {$[1]$} \\
\hline 2427 & orientalis & Gen. seq. & Russia & CIAM 0707 & {$[2,39]$} \\
\hline 2566 & orientalis & Gen. seq. & Caucasus & G058 & {$[40]$} \\
\hline 2605 & orientalis & Gen. seq., PCR & Caucasus & G091 & {$[40]$} \\
\hline 2610 & orientalis & Gen. seq., PCR & Caucasus & G096 & {$[40]$} \\
\hline 1141 & officinalis & Gen. seq. & New Zealand & & {$[1]$} \\
\hline 490 & officinalis & Gen. seq. & Finland & & {$[1]$} \\
\hline 1145 & officinalis & Gen. seq. & New Zealand & & {$[1]$} \\
\hline 1146 & officinalis & Gen. seq. & New Zealand & & {$[1]$} \\
\hline 1189 & officinalis & Gen. seq. & England & & {$[1]$} \\
\hline 2423 & orientalis & PCR & Caucasus & Rg843 & {$[2]$} \\
\hline 2433 & orientalis & PCR & Caucasus & Rg848 & {$[2,39]$} \\
\hline 2578 & orientalis & PCR & Caucasus & G060 & {$[40]$} \\
\hline 2586 & orientalis & PCR & Caucasus & G067 & {$[40]$} \\
\hline 2609 & orientalis & PCR & Caucasus & G094 & {$[40]$} \\
\hline 2635 & orientalis & PCR & Caucasus & G103 & {$[40]$} \\
\hline
\end{tabular}

${ }^{\mathrm{a}}$ Gen. seq., genome sequencing; PCR, used for PCR screening of $r p o N$ in symbiosis gene region. 
agarose gel. Strains used for screening are listed in Table 5.

\section{Genome sequencing, assembly and annotation}

Genomic DNA $(1 \mu \mathrm{g})$ was fragmented in a microTube $(100 \mu \mathrm{L})$ using Covaris S2 (LGC Genomics). Half of the fragmented DNA $(50 \mu \mathrm{L})$ was purified using a MinElute Reaction Cleanup kit (Qiagen) and eluted in $25 \mu \mathrm{L}$ EB buffer. End repair and A-tailing was done on the purified DNA $(25 \mu \mathrm{L})$ using DNA T4 Polymerase (7.5 U), T4 Polynucleotide Kinase (25 U), dNTP $(0.2 \mathrm{mM})$, DreamTaq DNA Polymerase $(1.25 \mathrm{U})$, ATP $(5 \mathrm{mM}), 2.5 \mu \mathrm{L} \mathrm{T} 4$ Polynucleotide Kinase Buffer A (10x) and $5 \mu \mathrm{L}$ T4 DNA Polymerase Buffer, in a total volume of $50 \mu \mathrm{L}$ (all enzymes from Fermentas). The reaction was incubated for $20 \mathrm{~min}$ at $25^{\circ} \mathrm{C}, 20 \mathrm{~min}$ at $72^{\circ} \mathrm{C}$ and $10 \mathrm{~min}$ at $4^{\circ} \mathrm{C}$. The reaction was purified using AMPure XP (Beckman Coulter Inc.) and eluted in $32 \mu \mathrm{L}$ water. Truncated Illumina forward (5'CTACACTCTTTCCCTACACGA CGCTCTTCCGATCT) and complementary reverse (5'Phos-GATCGGAAGAGCACACGTCTGAACTCCAG TCAC) primers were annealed to form a Y-Adapter $(2 \mu \mathrm{L} 20 \mu \mathrm{M})$ and ligated to the purified end-repaired DNA using $4 \mu \mathrm{L}$ T4 DNA Ligase buffer (10x), $2 \mu \mathrm{L}$ T4 DNA Ligase $(30 \mathrm{U} / \mu \mathrm{L}$, Fermentas) in a total volume of $40 \mu \mathrm{L}$ and incubation for $1 \mathrm{~h}$ at $25^{\circ} \mathrm{C}$. The ligation reaction was purified using AMPure XP and eluted in $25 \mu \mathrm{L}$ water. A final PCR was done in a $50 \mu \mathrm{L}$ reaction using KAPA HiFi DNA Polymerase (5 U), 8 pmol Illumina forward adapter (5'AATGATACGGCGACCACCGAGA TCTACACTCTTTCCCTACACGAC), Illumina reverse index primer (5'CAAGCAGAAGACGGCATACGAGAT XXXXXXGTGACTGGAGTTCAGACGTGT) and $5 \mu \mathrm{L}$ purified ligation reaction. The PCR cycle was $95^{\circ} \mathrm{C}$ for 3 min, 15 cycles of $95^{\circ} \mathrm{C}$ for $30 \mathrm{~s}, 60^{\circ} \mathrm{C}$ for $30 \mathrm{~s}$ and $72^{\circ} \mathrm{C}$ for $1 \mathrm{~min}$, and final extension at $72^{\circ} \mathrm{C}$ for $5 \mathrm{~min}$. The 6 bp indexes (XXXXXX in reverse index primer above) used were AAGCTA (HAMBI 490), CGTGAT (HAMBI 1145), TTAGGC (HAMBI 1146), GGAACT (HAMBI 1189), ATTATA (HAMBI 2427), GGCCAC (HAMBI 2566), CCGGTG (HAMBI 2605) and GTATAG (HAMBI 2610). The PCR reaction was purified using AMPure XP and eluted in a volume of $20 \mu \mathrm{L}$. The library was checked using Bioanalyzer on a DNA High Sensitive chip (Agilent Technologies). The concentration was measured using a High Sensitive kit on Qubit (Invitrogen). The libraries were pooled and sequenced in two partial paired-end runs on an Illumina MiSeq sequencer using the v2 and v3 sequencing kit.

The obtained MiSeq raw sequences from both sequencing rounds were subjected to quality filtering and overlapping sequences with a Phred quality score Q30 or above were extended using FLASH [23] and assembled using Newbler (Roche). Gene prediction was done with
Prodigal ver. 2.50 [24] followed by functional annotation with the PANNZER tool [25]. The tRNA genes were annotated using tRNAscan-SE 1.3.1 [26] and rRNA genes identified with RNAmmer 1.2 [27] and alignment to corresponding genes of HAMBI $540^{\mathrm{T}}$ and HAMBI 1141. The gene predictions of known symbiosis-related genes were manually checked. The draft genomes were submitted to the European Nucleotide Archive in the form of contigs [EMBL: ERS526350- ERS526357]. The sequences can be accessed through the link http://www.ebi.ac.uk/ena/ data/view/PRJEB6976.

\section{Mutant construction and verification}

Gene replacement deletion mutants of rpoN2 $(\Delta r p o N 2:: \Omega-\mathrm{Km})$ and nifQ $(\Delta$ nifQ:: $\Omega-\mathrm{Km})$ were constructed by marker exchange where the target gene was replaced with the $\Omega-\mathrm{Km}$ interposon [28] containing the $n p t I I$ gene. The rpoN2 gene was mutated in strain HAMBI $540^{\mathrm{T}}$ (mutant strain HAMBI 3480) and the nifQ gene in both HAMBI $540^{\mathrm{T}}$ (mutant strain HAMBI 3479) and HAMBI 1141 (mutant strain HAMBI 3481). Upstream flanking regions, the left arms, of the genes to be mutated were amplified (1167 bp for rpoN2, primers RpoNLLSpeI and RpoNLRBamHI; 1161 bp for HAMBI $540^{\mathrm{T}}$ nifQ, primers nifQLLSpeI-ori and nifQLRBamHI-ori; $1092 \mathrm{bp}$ for HAMBI 1141 nifQ, primers nifQLLSpeI-2 and nifQLRBamHI-2) as well as downstream flanking fragments, the right arms (1073 bp for rpoN2, primers RpoNRLBglII and RpoNRRXhoI; 1092 bp for nifQ in both HAMBI $540^{\mathrm{T}}$ and HAMBI 1141, primers nifQRLBamHI and nifQRRXhoI), using Phusion or DyNAzyme II polymerase (Thermo Scientific). Primer sequences are listed in Table 6. The amplified fragments contained short regions of the $5^{\prime}$ and $3^{\prime}$ ends respectively, of the genes. The primers contained restriction endonuclease sites (BamHI and SpeI for the left arm and BglII or BamHI and XhoI for the right arm) to facilitate directional cloning. The $\Omega-\mathrm{Km}$ interposon was released from $\mathrm{pHP} 45 \Omega-\mathrm{Km}$ [27] by BamHI digestion, purified and ligated along with the PCR products (digested with BamHI + SpeI and BglII/BamHI + XhoI respectively and purified) into pJQ200SK [29] that had been digested with SpeI and XhoI and dephosphorylated. The resulting constructs where the $\Omega-\mathrm{Km}$ interposon was inserted between the two PCR products was transferred into Escherichia coli S17-1 $\lambda$ pir by electroporation (ca $30 \mathrm{ng}$ of plasmid construct into $40 \mu \mathrm{L}$ of electrocompetent cells, electroporation at $2.5 \mathrm{kV}$, $25 \mu \mathrm{F}$ and $200 \Omega$ in $0.2 \mathrm{~cm}$ spaced cuvettes) and confirmed by restriction analysis and sequencing (sequencing primers T3 as well as gene-specific primers rpoNL-646, oriNifQL-570 or offNifQL-661 for the left arm; M13 UP as well as gene-specific primers rpoNR-413, oriNifQR-583 or offNifQR-560 for the right arm). The verified constructs were then transferred into E. coli ST18 [30], the donor 
Table 6 Primers used in this study

\begin{tabular}{|c|c|}
\hline Primer & Sequence $5^{\prime}-3^{\prime}$ \\
\hline \multicolumn{2}{|l|}{ PCR amplification } \\
\hline RpoNLLSpel & TITAAAACTAGTTTGATATCGTCACCAATGGC \\
\hline RpoNLRBamHI & AAATTTGGATCCGTTTCATTCAGAGCTCCTG \\
\hline nifQLLSpel-ori & TTAAAACTAGTCGATCGTCGTGAGCGCAATG \\
\hline nifQLRBamHI-ori & AAATTTGGATCCAGTTTCCATCCTGCGACCTC \\
\hline nifQLLSpel-2 & AAATTTACTAGTGCTGCATCTCGGGAGGTCGAT \\
\hline nifQLRBamHI-2 & TITAAAGGATCCAGCCATCTCGCAATTCACAGCG \\
\hline RpoNRLBgl|I & AAATTTAGATCTITCTGACTCTGTCATGCTTC \\
\hline RpoNRRXhol & TITAAACTCGAGGTCCATAGTAAGTGCCGTGA \\
\hline nifQRLBamHI & AAATTTGGATCCCGACAATGATTGCGAATCAAGC \\
\hline nifQRRXhol & TTAAACTCGAGCGGCCGAACCCTITGAACTC \\
\hline rpoNmutLL & AAACAAGATCATGCCATCGG \\
\hline 540nifQL-1234F & TAGTCCGCCTGAGTCCAGAG \\
\hline 1141nifQL-1184F & GCTTGTGATTGACGAGGTG \\
\hline hsnTmutLR & ACTATCAGGTCAAGTCTGCT \\
\hline hsnTmutRL & TTGATGTTACCCGAGAGCTT \\
\hline rpoNmutRR & CTTCATCCGATCCTGGAGTA \\
\hline nifQR-1209R & TCGCTATTGCATTGCCGATT \\
\hline \multicolumn{2}{|l|}{ Sequencing } \\
\hline rpoNL-646 & TGCAGTACAGCGATTGTGACG \\
\hline oriNifQL-570 & TGACGCAAGCAGTCGGCAAC \\
\hline offNifQL-661 & CATGGCAACGATGGCAAGTC \\
\hline rpoNR-413 & GCAACCGCAACGTGTATTCG \\
\hline oriNifQR-583 & GGATATTGCCATCCGCGAAG \\
\hline offNifQR-560 & TACCGAGATGAACAGCACCTG \\
\hline
\end{tabular}

strain used to transfer each construct into $R$. galegae HAMBI $540^{\mathrm{T}}$ and HAMBI 1141 (nifQ only) by biparental spot mating. Mating was conducted by mixing stationaryphase recipient with late log-phase or stationary-phase donor, pelleting the cells, followed by resuspension in $50 \mu \mathrm{l}$ of MilliQ water and spotting on a TY plate with 5-aminolevulinic acid (ALA; $50 \mu \mathrm{g} / \mathrm{mL}$ ). Exconjugants were plated onto def8 agar [31] containing $5 \%$ sucrose and neomycin $(25 \mu \mathrm{g} / \mathrm{mL})$, or TY agar containing $5 \%$ sucrose and neomycin $(50 \mu \mathrm{g} / \mathrm{mL})$, to select for cells in which the suicide plasmid had been inserted and PJQ200SK removed via recombination events. Mutant candidate clones were colony purified on TY $(\mathrm{Nm} 50 \mu \mathrm{g} / \mathrm{mL})$ plates and tested for sensitivity to gentamicin. The final neomycin resistant, gentamicin sensitive gene replacement mutants were further confirmed by PCR analysis and sequencing. The insert-flanking regions were amplified with two sets of primers: rpoNmutLL $(r p o N)$, 540nifQL-1234 F (HAMBI $540^{\mathrm{T}}$ nifQ) or 1141nifQL-1184 F (HAMBI 1141 nifQ) together with hsnTmutLR, amplifying from within the Rhizobium DNA upstream of the left arm to the 5' end of the interposon; and primers hsnTmutRL and rpoNmutRR (rpoN) or nifQR-1209R (HAMBI 540 ${ }^{\mathrm{T}}$ and 1141 nifQ), amplifying a fragment from within the $3^{\prime}$ end of the interposon to the Rhizobium DNA downstream of the right arm. These PCR fragments were sequenced over the junctions to confirm that homologous recombination had worked properly.

The mutant strains were finally whole-genome sequenced to verify that the insert was present only in the intended location, replacing the deleted gene, and that no other deviations from the reference strain were present. Total DNA of the strains was isolated using the CTAB method as described in section "DNA isolation". Sequencing was done on an Illumina MiSeq sequencer as described above for the eight genome-sequenced strains, using the v3 sequencing kit, to coverages of $26 \times$ (HAMBI 3480), $23 \times$ (HAMBI 3479) and $24 \times$ (HAMBI 3481). Raw sequence reads were quality filtered and the sequences with a Phred quality score Q25 or above were extended with FLASH [23] and both extended and non-extended fragments assembled using Newbler (Roche). The resulting contigs were then mapped to the reference genome (HAMBI $540^{\mathrm{T}}$ or HAMBI 1141) using the BWA-SW algorithm of the BWA software package [32]. The mapping results were then manually checked for consistency.

\section{Plant tests of mutants}

Nodulation tests of the mutant strains were performed on their respective original hosts, Galega orientalis or Galega officinalis. G. orientalis seeds were surface sterilised by washing the seeds in $96 \%$ ethanol for 1 minute, 3\% sodium hypochlorite for 3-5 minutes and washing with sterile water 5-6 times for 1-2 minutes. The sterilised seeds were germinated on TY agar plates at room temperature in darkness. G. officinalis seeds were surface sterilised by the following procedure: washed with concentrated sulphuric acid for 15 minutes, rinsed with sterile water 8 times for 2 minutes, kept in $96 \%$ ethanol for 1 minute and finally washed with sterile water 6 times for 2-5 minutes. Germinated seeds were transferred to glass jars containing a mixture of Leca gravel $(4-10 \mathrm{~mm})$, sand $(0.5-1.2 \mathrm{~mm})$ and vermiculite. The components were washed and mixed at a ratio 3:5:5, jars were filled with the mixture and sterilised at $160^{\circ} \mathrm{C}$ for $24 \mathrm{~h}$. Each jar (containing about $700 \mathrm{~mL}$ of soil mixture) was watered with $125 \mathrm{~mL}$ quarter-strength nitrogen-free Jensen medium [33] before seeds were planted, three plants per jar. Inoculant strains were grown in TY medium to an $\mathrm{OD}_{600}$ of about 1.0, pelleted and resuspended in water, and plant seedlings inoculated with $1 \mathrm{~mL}$ bacterial suspension. Negative control seedlings were inoculated with $1 \mathrm{~mL}$ of sterile MilliQ water. Inoculated seedlings were covered and each jar watered with $50 \mathrm{~mL}$ sterile water. Plants were then grown in a growth chamber 
$\left(20^{\circ} \mathrm{C}\right.$ for $1 \mathrm{~h}, 24^{\circ} \mathrm{C}$ for $16 \mathrm{~h}, 20^{\circ} \mathrm{C}$ for $1 \mathrm{~h}, 16^{\circ} \mathrm{C}$ for $6 \mathrm{~h}$ with darkness) for four weeks.

\section{Greenhouse experiment}

The bacterial strains used to inoculate G. orientalis plants were cultured on yeast mannitol agar (YMA) medium at $28^{\circ} \mathrm{C}$ for 2 days, followed by culture of single colonies in 50 $\mathrm{ml} \mathrm{TY}$ medium at $28^{\circ} \mathrm{C}$ for 48 hours. The bacterial cultures were centrifuged and the pellets resuspended in sterile water (cell density of $1 \times 10^{8}$ cells $/ \mathrm{mL}$ ). G. orientalis seeds were sterilized as described above, and sown in pots $(3 \mathrm{~L}$, $15 \mathrm{~cm}$ high, $19 \mathrm{~cm}$ in diameter) filled with a coarse potting mix (Kekkilä) (N-P-K 14-4-20, pH 5.4), 6 seeds per pot. Each seed was inoculated with $1 \mathrm{~mL}$ of bacterial suspension (sterile water for the uninoculated control). The plants were grown under climate-controlled greenhouse conditions, applying a randomized complete block design with 6 replicates. The greenhouse conditions were as follows: relative humidity 70\% (weeks $0-3$ ) or $40 \%$ (weeks 4-7), and a 16-hour photo period with a temperature of $24^{\circ} \mathrm{C}$ at day and $15^{\circ} \mathrm{C}$ at night. The number of seedlings per pot was thinned out to 3 seedlings 10 days after inoculation. The plants were harvested after 7 weeks to ensure that the nitrogen content of soil was depleted, and a second harvest was done 42 days after the first harvest. After the second harvest, the aerial parts of the plants were dried at $75^{\circ} \mathrm{C}$ and dry weights determined as the sum of all plants from the same pot. For strains HAMBI 2605 and HAMBI 2610, growth of one plant in one pot each failed, reducing the number of pots included in dry weight measurements for these strains to 5 .

\section{Bioinformatics analyses}

The OrthoMCL software [34] was used to find ortholog groups between the eight newly sequenced strains of $N$. galegae and the two reference strains HAMBI $540^{\mathrm{T}}$ and HAMBI 1141 [4], as well as between HAMBI $540^{\mathrm{T}}$, HAMBI 1141 and eight related rhizobial species: $S$. medicae WSM419, S. meliloti 1021, S. fredii NGR234, $R$. leguminosarum bv. viciae $3841, R$. leguminosarum bv. trifolii WSM2304, $R$. etli bv. mimosae str. Mim1, $R$. tropici CIAT 899, M. ciceri bv. biserrulae WSM1271. The software was run with default settings. Custom Perl, Python and Biopython [35] scripts were used to modify output from these analyses. Alignment of NifQ proteins (accession numbers of previously published sequences: $A$. vinelandii AAA22151, K. pneuomonie WP_032733323, S. fredii HH103 AAG37298, Rhizobium tropici CIAT 899 AGB73564, HAMBI 540 ${ }^{\mathrm{T}}$ CDN51705, HAMBI 1141 CDN58442) was done using MUSCLE [36] and manually curated. Prediction of RpoN binding sites was carried out using the TFBS prediction of the online tool PePPER [37]. Both E. coli K12 RpoN and B. japonicum USDA 110 RpoN1, available in PePPER, were considered when the intergenic regions of the sv. orientalis-specific genes were searched for RpoN binding sites.

\section{Availability of supporting data}

The data sets supporting the results of this article are included within the article and its additional files. The genome sequences of $N$. galegae strains HAMBI 490, HAMBI 1145, HAMBI 1146, HAMBI 1189, HAMBI 2427, HAMBI 2566, HAMBI 2605 and HAMBI 2610 are publicly available as contigs in the European Nucleotide Archive [EMBL:CCRG01000001-CCRG01000130 (HAMBI 490), EMBL:CCRH01000001-CCRH01000066 (HAMBI 1145), EMBL:CCRI01000001-CCRI01000054 (HAMBI 1146), EMBL:CCRK01000001-CCRK01000060 (HAMBI 1189), EMBL:CCRJ01000001-CCRJ01000065 (HAMBI 2427), EMBL:CCRL01000001-CCRL01000099 (HAMBI 2566), EMBL:CCRM01000001-CCRM01000148 (HAMBI 2605), EMBL:CCRN01000001-CCRN01000059 (HAMBI 2610)].

\section{Additional file}

Additional file 1: This table lists the functional annotations of genes in the $\mathbf{4 4 1}$ ortholog groups that define $N$. galegae-specific genes when analysis of the ten $N$. galegae strains was combined with analysis of the reference genomes $\mathrm{HAMBI} 540^{\top}$ and $\mathrm{HAMBI} 1141$ with eight other rhizobial genomes (S. medicae WSM419, S. meliloti 1021, S. fredii NGR234, R. leguminosarum bv. viciae 3841 , $R$. leguminosarum bv. trifolii WSM2304, R. etli bv. mimosae str. Mim1, R. tropici CIAT 899, M. ciceri bv. biserrulae WSM1271). The genes of strain HAMBI 2427 are given as representatives of the whole ortholog group.

\section{Abbreviations}

sV.: Symbiovar; T4SS: Type IV secretion system; T6SS: Type VI secretion system; QS: Quorum sensing; CDS: Protein-coding DNA sequence; ABC transporter: ATP-binding cassette transporter; NO: Nitric oxide; TA: Toxin-antitoxin; ALA: 5-aminolevulinic acid; TY: Tryptone yeast; YMA: Yeast mannitol agar.

\section{Competing interests}

The authors declare that they have no competing interests.

\section{Authors' contributions}

JÖ designed the study, performed genome assembly, manual annotation and bioinformatics analyses. JÖ also performed experimental laboratory work and drafted the manuscript. SAM performed greenhouse experiments and contributed to writing the results of the same. PK contributed with expert advice on annotation strategy, ran the functional annotation pipeline and contributed to finalisation of the manuscript. LP was responsible for design and coordination of genome sequencing, and participated in modifying the final version of the manuscript. KL participated in coordination and design of the study, and contributed to final modifications of the manuscript. All authors read and approved the final manuscript.

\section{Acknowledgements}

We acknowledge Juhana Kammonen for instructions and advice on genome assembly. Technical staff at the DNA sequencing and Genomics laboratory, Institute of Biotechnology, University of Helsinki, is acknowledged for assistance in preparation of genomic material for sequencing. We used the resources of the CSC (Finnish IT Center for Science, Helsinki, Finland) Hippu and Taito clusters for sequence analysis. The work was done as part of the SYMBEF project supported by the Academy of Finland (project 132544). JÖ acknowledges support from the Swedish Cultural Foundation in Finland (grant 13/7440-1304). 


\section{Author details}

'Department of Food and Environmental Sciences, University of Helsinki, Viikinkaari 9, 00790 Helsinki, Finland. Department of Environmental Sciences, University of Helsinki, Viikinkaari 2a, 00790 Helsinki, Finland. ${ }^{3}$ Institute of Biotechnology, University of Helsinki, Viikinkaari 9, 00790 Helsinki, Finland.

Received: 22 January 2015 Accepted: 24 April 2015

Published online: 02 May 2015

\section{References}

1. Lindström K. Rhizobium galegae, a new species of legume root nodule bacteria. Int J Syst Bacteriol. 1989;39:365-7.

2. Radeva G, Jurgens G, Niemi M, Nick G, Suominen L, Lindström K. Description of two biovars in the Rhizobium galegae species: biovar orientalis and biovar officinalis. Syst Appl Microbiol. 2001;24:192-205.

3. Yang G, Debellé F, Savagnac A, Ferro M, Schiltz O, Maillet F, et al. Structure of the Mesorhizobium huakuii and Rhizobium galegae Nod factors: a cluster of phylogenetically related legumes are nodulated by rhizobia producing Nod factors with a, $\beta$-unsaturated N-acyl substitutions. Mol Microbiol. 1999:34:227-37.

4. Österman J, Marsh J, Laine PK, Zeng Z, Alatalo E, Sullivan JT, et al. Genome sequencing of two Neorhizobium galegae strains reveals a noeT gene responsible for the unusual acetylation of the nodulation factors. BMC Genomics. 2014;15:500

5. Ding H, Yip CB, Hynes MF. Genetic characterization of a novel rhizobial plasmid conjugation system in Rhizobium leguminosarum bv. viciae strain VF39SM. J Bacteriol. 2013;195:328-39.

6. Galardini M, Mengoni A, Brilli M, Pini F, Fioravanti A, Lucas S, et al. Exploring the symbiotic pangenome of the nitrogen-fixing bacterium Sinorhizobium meliloti. BMC Genomics. 2011;12:235

7. González V, Acosta JL, Santamaría RI, Bustos P, Fernández JL, Hernández González IL, et al. Conserved symbiotic plasmid DNA sequences in the multireplicon pangenomic structure of Rhizobium etli. Appl Environ Microbiol. 2010;76:1604-14.

8. Poggio S, Osorio A, Dreyfus G, Camarena L. Transcriptional specificity of RpoN1 and RpoN2 involves differential recognition of the promoter sequences and specific interaction with the cognate activator proteins. J Biol Chem. 2006;281:27205-15.

9. Kullik I, Fritsche S, Knobel H, Sanjuan J, Hennecke H, Fischer HM. Bradyrhizobium japonicum has two differentially regulated, functional homologs of the sigma 54 gene (rpoN). J Bacteriol. 1991;173:1125-38.

10. Michiels J, Moris M, Dombrecht B, Verreth C, Vanderleyden J. Differential regulation of Rhizobium etli rpoN2 gene expression during symbiosis and free-living growth. J Bacteriol. 1998;180:3620-8.

11. Sullivan JT, Brown SD, Ronson CW. The NifA-RpoN regulon of Mesorhizobium loti strain R7A and its symbiotic activation by a novel Lacl/GalR-family regulator. PLOS ONE. 2013;8, e53762.

12. Barrios H, Valderrama B, Morett E. Compilation and analysis of $\sigma 54$ dependent promoter sequences. Nucleic Acids Res. 1999;27:4305-13.

13. de Boer APN, van der Oost J, Reijnders WNM, Westerhoff HV, Stouthamer AH, van Spanning RJM. Mutational analysis of the nor gene cluster which encodes nitric-oxide reductase from Paracoccus denitrificans. Eur J Biochem. 1996:242:592-600.

14. Bartnikas TB, Wang Y, Bobo T, Veselov A, Scholes CP, Shapleigh JP. Characterization of a member of the NnrR regulon in Rhodobacter sphaeroides 2.4 .3 encoding a haem-copper protein. Microbiology. 2002;148:825-33.

15. Baudouin E, Pieuchot L, Engler G, Pauly N, Puppo A. Nitric oxide is formed in Medicago truncatula-Sinorhizobium meliloti functional nodules. Mol Plant Microbe Interact. 2006;19:970-5.

16. Shimoda $Y$, Nagata M, Suzuki A, Abe M, Sato S, Kato T, et al. Symbiotic rhizobium and nitric oxide induce gene expression of non-symbiotic hemoglobin in Lotus japonicus. Plant Cell Physiol. 2005;46:99-107.

17. David M, Daveran M, Batut J, Dedieu A, Domergue O, Ghai J, et al. Cascade regulation of nif gene expression in Rhizobium meliloti. Cell. 1988;54:671-83.

18. Mesa S, Bedmar EJ, Chanfon A, Hennecke H, Fischer H. Bradyrhizobium japonicum NnrR, a denitrification regulator, expands the Fix L-FixK2 regulatory cascade. J Bacteriol. 2003;185:3978-82.

19. de Bruijn FJ, Rossbach S, Bruand C, Parrish JR. A highly conserved Sinorhizobium meliloti operon is induced microaerobically via the FixLJ system and by nitric oxide (NO) via NnrR. Environ Microbiol. 2006;8:1371-81.
20. van der Ploeg JR, Cummings NJ, Leisinger T, Connerton IF. Bacillus subtilis genes for the utilization of sulfur from aliphatic sulfonates. Microbiology. 1998;144:2555-61.

21. Sugawara M, Shah GR, Sadowsky MJ, Paliy O, Speck J, Vail AW, et al. Expression and functional roles of Bradyrhizobium japonicum genes involved in the utilization of inorganic and organic sulfur compounds in free-living and symbiotic conditions. Mol Plant Microbe Interact. 2011;24:451-7.

22. Bodogai M, Ferenczi S, Bashtovyy D, Miclea P, Papp P, Dusha I. The ntrPR operon of Sinorhizobium meliloti is organized and functions as a toxin-antitoxin module. Mol Plant Microbe Interact. 2006;19:811-22.

23. Magoč T, Salzberg SL. FLASH: fast length adjustment of short reads to improve genome assemblies. Bioinformatics. 2011;27:2957-63.

24. Hyatt D, Chen G, LoCascio P, Land M, Larimer F, Hauser L. Prodigal: prokaryotic gene recognition and translation initiation site identification. BMC Bioinformatics. 2010;11:119.

25. Koskinen P, Törönen P, Nokso-Koivisto J, Holm L. PANNZER - High-throughput functional annotation of uncharacterized proteins in an error-prone environment. Bioinformatics. 2015. doi:10.1093/bioinformatics/btu851

26. Lowe TM, Eddy SR. tRNAscan-SE: a program for improved detection of transfer RNA genes in genomic sequence. Nucleic Acids Res. 1997;25:955-64.

27. Lagesen K, Hallin P, Rødland EA, Stærfeldt H, Rognes T, Ussery DW. RNAmmer: consistent and rapid annotation of ribosomal RNA genes. Nucleic Acids Res. 2007:35:3100-8.

28. Fellay R, Frey J, Krisch H. Interposon mutagenesis of soil and water bacteria: a family of DNA fragments designed for in vitro insertional mutagenesis of Gram-negative bacteria. Gene. 1987:52:147-54

29. Quandt J, Hynes MF. Versatile suicide vectors which allow direct selection for gene replacement in Gram-negative bacteria. Gene. 1993;127:15-21.

30. Thoma S, Schobert M. An improved Escherichia coli donor strain for diparental mating. FEMS Microbiol Lett. 2009;294:127-32.

31. Lindström K, Lehtomäki S. Metabolic properties, maximum growth temperature and phage sensitivity of Rhizobium sp. (Galega) compared with other fast-growing rhizobia. FEMS Microbiol Lett. 1988;50:277-87.

32. Li H, Durbin R. Fast and accurate long-read alignment with Burrows-Wheeler transform. Bioinformatics. 2010;26:589-95.

33. Vincent JM. A manual for the study of root-nodule bacteria (IBP Handbook No. 15). Oxford: Blackwell Scientific Publications; 1970.

34. Li L, Stoeckert CJ, Roos DS. OrthoMCL: identification of ortholog groups for eukaryotic genomes. Genome Res. 2003;13:2178-89.

35. Cock PJ, Antao T, Chang JT, Chapman BA, Cox CJ, Dalke A, et al. Biopython: freely available Python tools for computational molecular biology and bioinformatics. Bioinformatics. 2009:25:1422-3.

36. Edgar RC. MUSCLE: multiple sequence alignment with high accuracy and high throughput. Nucleic Acids Res. 2004;32:1792-7.

37. de Jong A, Pietersma H, Cordes M, Kuipers OP, Kok J. PePPER: a webserver for prediction of prokaryote promoter elements and regulons. BMC Genomics. 2012;13:299-2164-13-299.

38. Hernandez JA, Curatti L, Aznar CP, Perova Z, Britt RD, Rubio LM. Metal trafficking for nitrogen fixation: NifQ donates molybdenum to NifEN/NifH for the biosynthesis of the nitrogenase FeMo-cofactor. Proc Natl Acad Sci U S A. 2008;105:11679-84.

39. Terefework Z, Kaijalainen $S$, Lindström K. AFLP fingerprinting as a tool to study the genetic diversity of Rhizobium galegae isolated from Galega orientalis and Galega officinalis. J Biotechnol. 2001;91:169-80.

40. Andronov EE, Terefework Z, Roumiantseva ML, Dzyubenko NI, Onichtchouk $\mathrm{OP}$, Kurchak ON, et al. Symbiotic and genetic diversity of Rhizobium galegae isolates collected from the Galega orientalis gene center in the Caucasus. Appl Environ Microbiol. 2003;69:1067-74. 